\title{
Exploring the Rhetorical Use of Interactional Metadiscourse: A Comparison of Letters to Shareholders of American and Chinese Financial Companies
}

\author{
Liu Xiaoqin ${ }^{1}$ \\ ${ }^{1}$ School of English for International Business, Guangdong University of Foreign Studies, Guangzhou, China \\ Correspondence: Liu Xiaoqin, Room 2101, Building A2, Huajingli, Huajingxincheng, Tianhe District, \\ Guangzhou 510630, Guangdong province, China. Tel: 18925150380.E-mail: 15552016@qq.com
}

Received: April 29, 2017 Accepted: June 10, 2017 Online Published: June 13, 2017

doi: 10.5539/elt.v10n7p232 URL: http://doi.org/10.5539/elt.v10n7p232

\begin{abstract}
By taking Hyland and Tse's (2004) interactional metadiscourse model, this study attempts to compare the incidence of the interactional metadiscourse markers in letters to shareholders of American and Chinese companies in the financial industry and their rhetorical functions. This study makes American corpus of 41 letters and Chinese corpus of 37 letters both of which are written in English. WordSmith is adopted to find out the differences in incidence of these markers. Chi-square test further confirms these differences are significant. It is consequently found that five types of interactional metadiscourse markers are all deployed in both American and Chinese corpus but the incidence of each marker is much more in American corpus than that in Chinese corpus. Besides, this study identifies that self-mentions and engagement markers are the most frequently employed in both corpora. However, it is noticeable that self-mentions and engagement markers collaborate with another three types of markers more tactically and flexibly in American corpus than in Chinese. In particular, self-mentions markers are found to use with not only boosters, but hedges and engagement markers in American corpus, while self-mentions markers in Chinese corpus only collaborate with hedges. In addition, the engagement markers of model verbs and personal pronouns are more active in American corpus than these in Chinese. This study finds out American companies integrate these markers into building a positive personal or corporate image and closing writer-reader relationship, thereby accomplishing the promotional and persuasive purposes. It may suggest that Chinese companies employ the integration of interactional metadiscourse markers as strategically as American.
\end{abstract}

Keywords: the letter to shareholders, interactional metadiscourse, rhetorical functions, persuasion

\section{Introduction}

The annual report is regarded as the most important document which reviews and discloses the corporate performance of the previous fiscal year. The letter to shareholders signed by Chairman (CEO or President) of a company normally precedes the more substantial and detailed financial data. It is found that the letter is the most prominent and widely read portion of the annual report (Hyland, 1998, p. 224). Hyland (2005) points out that the letter to shareholders is an ostensibly informative genre which lists out the information and seemingly objective evaluation of the company's activities, performance and future plans, while it in fact goes beyond purely passive disclosure to what amounts to the marketing of a corporate ideology (p. 74). Conaway and Wardrope (2010) also argue that the letter is a crucial sense-giving instrument which motivates more interpretive and affective reactions than a mere factual overview of the corporate performance and progress (Amernic et al., 2010; Yuthas et al., 2002).Therefore, the letter is widely regarded as a promotional genre which is designed to build and convey a corporate positive image to the stakeholders (Anderson \& Imperia, 1992, p. 114). It is not surprising that the letter must be in nature a selectively created persuasive product and plays more rhetorical functions such as building credibility, imparting confidence, persuading or convincing the readers than delivering the fiscal information.

Metadisourse is the author's linguistic and rhetorical manifestation in the text in order to 'bracket the discourse organization and the expressive implications of what is being said' (Schiffrin, 1980, p. 231). It is widely adopted to be a framework for analyzing interactions in both written and spoken discourse, giving a means to examine 
the ways in which writers (speakers) construct both texts and audience and how they interact with their prospective readers (Hyland, 2002a, p. 1111). Fuerters-Olivera et al. (2001), for example, state that metadiscourse conveys 'a persuasive message under an informative mask' (p. 1305). And Aristotle's rhetoric is assumed to be an endeavor to comprehend persuasion systematically. Hyland (2005) clarifies that rhetoric is the art of persuasion (p. 63) and different metadiscourse items have distinct rhetorical effects (p. 84). Therefore, this study explores the rhetoric functions of interactional metadiscourse markers, which gives an insight to the persuasive and promotional purposes of the letter.

This study exclusively focuses on the classical rhetorical pragmatic functions of credible appeals (ethos) and affective appeals (pathos) which appropriately address the letter's communicative purposes of promotion and persuasion. By combining interactional metadiscourse and rhetoric, there is an attempt to compare the distinctive features in interactional metadiscourse markers deployment and their rhetorical functions of projecting credibility and affective appeals in American and Chinese corpus respectively, which helps the writer to create a positive personal or corporate image and then achieve persuasive goals in the letter.

\section{Literature Review}

\subsection{The Concept of Metadiscourse}

The concept of metadiscourse is firstly introduced by Harris (1959) and initially defined as a way in which people understand the use of language or the writers (speakers) leading the audience to comprehend the discourse. With the ongoing research, the term is further developed by many researchers (Crismore, 1989; Hyland, 2000, 2002b, 2005; Hyland \& Tse, 2004; Mirshamsi \& Allami, 2013; Vande Kopple, 1985; Williams, 1981). These definitions and explanations put forward above can be generalized into the idea that metadiscourse tightly links the writers (speakers) who compose or speak discourse with the audience who receive the messages and analyze them. To be more specific, this study takes Hyland (2005) definition to further standardize the concept of metadiscourse in this research environment:

'metadiscourse is the cover term for the self-reflective expressions used to negotiate interactional meanings in a text, assisting the writer (or speaker) to express a viewpoint and engage with readers as members of a particular community'(p. 37).

Based on the functionally oriented perspective, three principles of metadiscourse (Hyland \& Tse, 2004) should be complied with. Firstly, the metadiscourse is different from thematical or propositional aspects of discourse, and then metadsicourse refers to aspects of the text that embody writer-reader interactions, and finally metadiscoure distinguishes relations which are external to the text from those that are internal (p.159). Bearing these core concepts in mind, this study concentrates on the writer-reader interactions and is to exploit how the writer establishes a credible image and involves, galvanizes or convinces the reader by the use of metadiscourse. In this aspect, this study is not only relevant to the proposition and internal message in the letters but more related to interactions between the writer and reader.

Vande Kopple (1985) firstly presents the model of metadiscourse in the literature. Thereafter, a large number of models of metadiscourse (Ädel, 2006; Bunton, 1999; Crismore, 1989; Hyland, 1998 and 2000; Thompson, 2001; Vande Kopple, 2002) have been discussed. Building on these earlier models of metadiscourse, Hyland and Tse (2004) borrow two delicate terms of interactive and interactional from Thompson and Thtela's (1995) and propose a more "robust" and functional model of metadiscourse which better distinguishes metadiscourse from the propositional content of a text. This model is more broadly conceptualized as an interpersonal feature of communication.

Hyland and Tse (2004) states that the interactive metadicourse is composed of the resources which are used to organize propositional information to clearly build the writer's preferred interpretations rather than experience, to anticipate the reader's knowledge and reflect the writer's assessment of what needs to be made explicit to constrain and guide what can be recovered from the text (p. 168). This study aims to explore the interpersonal power of interactional metadiscourse by accentuating its crucial role in realizing the appeals of classical rhetoric in the promotional genre of the letter to the shareholders. The interactive metadiscourse is therefore temporarily ignored in my study.

The interactional resources demonstrate the way in which the writer manages the interaction. Interactional metadiscourse markers are assumed to further determine the level of subjectivity in a text, which fully exhibits the guidance of the writer (Hyland, 2005, p. 52). These interactional markers are specifically composed of attitude markers, boosters, self-mentions, engagement markers and hedges which closely align the aims or intentions of the writer or the speaker with the reader's, thereby involving the reader. 
Table 1. Interactional metadiscourse model (Hyland \& Tse, 2004, p. 169)

\begin{tabular}{|c|c|c|}
\hline Interactional resources & Involve the reader in the argument & Markers \\
\hline \multirow{3}{*}{ hedges } & withhold writer's full & \multirow{3}{*}{ would/should/ might/ may/ could } \\
\hline & commitment to & \\
\hline & proposition & \\
\hline & emphasize force or & \multirow{3}{*}{ believe/think/always/know/must(possibility) } \\
\hline boosters & writer's certainty in & \\
\hline & proposition & \\
\hline attitude markers & $\begin{array}{l}\text { express writer's } \\
\text { attitude to proposition }\end{array}$ & expected/unfortunately/important/ essentially \\
\hline engagement markers & $\begin{array}{l}\text { explicitly refer to or } \\
\text { build relationship with } \\
\text { reader }\end{array}$ & have to/ must/need to/ should/see/add/ look at \\
\hline self-mentions & $\begin{array}{l}\text { explicit reference to } \\
\text { Author(s) }\end{array}$ & I/we/us/our \\
\hline
\end{tabular}

The specific metadiscourse example markers listed in the table are found in this study data.

\subsection{The Previous Studies of the Rhetorical Use of Metadiscourse}

To date, metadiscourse has been widely applied to variety of genres in casual conversation (Aerts \& Yan, 2017; Schiffrin, 1980), school textbooks (Crismore, 1989; Hyland, 2000), science popularisations (Crismore \& Farnsworth, 1990), company annual reports (Hyland, 1998), business e-mails (Carrio \&Calderon, 2015), postgraduate dissertations (Bunton, 1999), and research articles (Dahl, 2004; Hyland \& Jiang, 2016; Kan, 2016; $\mathrm{Mu}$, et al., 2015). A small amount of comparative research has been done. Kan (2016) conducts a comparative study which aims to determine the distinctive use of interactional metadiscouse in articles from the domains of Turkish Education and literature written in Turkish. The study takes Hyland and Tse's metadiscourse model as the framework and examines the incidence in the markers of interactional metadiscourse in all fundamental parts of 20 articles. It further validates the significance of these differences by Mann-Whitney U test. The study is conducted in the context of two different disciplines and the language is Turkish. With the interactional metadiscourse markers in English, It doubts whether there may be losses in both semantically and functionally in the process of translating Turkish to English. Ozdemir and Longo (2014) investigate cultural variations in the use of metadiscourse between Turkish and USA postgraduate students' abstracts in MA thesis written in English. The study also compares the incidence of both interactive and interactional metadiscourse markers between 26 theses of USA students and 26 of Turikish students. With a different genre of research data, this study focuses on finding out the differences in incidence of interactional metadiscourse markers, and further explores their rhetoric use in realizing credible and affective appeals.

Besides, there are only a few studies which apply linguistic characteristics to examining rhetorical functions in corporate reports (Crawford Camiciottoli, 2010; Dragsted, 2014; Hyland, 1998, 2005). These studies investigate how metadiscourse markers are used as instruments to realize three rhetorical functions of rational ('logos'), credible ('ethos') and affective ('pathos') appeals, which facilitates connecting the writer to the reader. Hyland (1998) compares the rhetorical effect of metadiscourse between CEO letters and director's reports in which the metadiscourse markers are divided into textual and interpersonal items. By contrast, this study takes the improved metadiscourse framework by Hyland and Tse (2004) and further explores the cross-cultural factors which inherently lead to the distinctive features of interactional metadiscourse between American and Chines corpus. Aerts and Yan (2017) explore rhetorical impression management in the letter to shareholders from a metadiscourse perspective (p. 404) and how a company's institutional context have an influence on incentives and constraints for rhetorical impression management. The study compares the casual language and other metadiscourse devices between USA and UK where English is the native language for speakers. This study focuses on the cross-cultural varieties in the use of interactional metadiscourse between American and Chinese companies, which is ambitious to offer some suggestions to Chinese companies on how to strategically deploy interactional metadiscourse markers, in order to involve the writer with the reader more effectively. 


\section{Method}

\subsection{Research Questions}

Hyland (1998) has shown the extent to which metadiscourse is a ubiquitous feature by which CEOs portray themselves and their companies positively. This study is interested in the relationship between interactional metadiscourse and business persuasion and attempts to reveal the distinctive strategies in deploying the interactional metadiscourse items to realize the rhetorical functions of the specific genre. With the general purpose, three specific research questions are listed as follows:

1) What are the types of interactional metdadiscourse and their frequencies in American and Chinese corpus respectively?

2) Is there any significant difference in the use of interactional metadiscourse items between American and Chinese corpus according to Chi-square test?

3) How distinctively do American and Chinese letters create credible and affective appeals by employing interactional metadiscourse?

\subsection{Data Collection}

American corpus consisting of 41 letters and Chinese corpus of 37 ones are simultaneously built up. These letters are all extracted from the annual reports of the companies on world top 500 in 2014 and 2015. These letters are not randomly chosen but constrain to the discipline of finance industry including banks, insurance, and investment etc. There are totally 145,897 tokens in American corpus compared to 58,041tokens in Chinese corpus.

In an attempt to improve the reliability and validity of the research, the study adopts both the quantitative and qualitative research methods. Relying on the corpus and Chi-square test, interactional metadiscourse items in Hyland and Tse's (2004) model are thoroughly examined. Firstly the function of concordance in WordSmith is applied to find out the deployment of each interactional metadiscourse marker and their frequency statistically. Due to the unequal size (tokens) of the two corpora, interactional metadiscourse markers are counted per 1,000 tokens, which sounds more reasonable to observe and compare the differences. And Chi-square test is further applied to determine whether the differences in incidence of interactional metadiscourse markers shows any significance.

\section{Findings and Discussion}

\subsection{The Types of Interactional Metadiscourse and Their Frequency}

The table below presents that five types of attitude markers, boosters, self-mentions, engagement markers, and hedges in Hyland and Tse's interactional metadiscourse model are all employed in the letters by American and Chinese Chairmen (CEOs or Presidents). Moreover, their incidence per 1,000 words and frequency are presented in the Table 2.

Table 2. Interactional metadiscourse types in American and Chinese corpus

\begin{tabular}{lllll}
\hline Interactional metadiscourse type & American corpus & \multicolumn{3}{l}{ Chinese corpus } \\
\hline & per1,000 tokens & frequency & per1,000 tokens & frequency \\
attitude markers & 4.02 & 587 & 1.43 & 83 \\
boosters & 7.23 & 1055 & 3.02 & 175 \\
self-mentions & 54.53 & 7956 & 25.41 & 1475 \\
engagement markers & 63.17 & 9216 & 31.32 & 1818 \\
hedges & 10.82 & 1579 & 3.31 & 192 \\
total & 139.78 & 20393 & 64.49 & 3743 \\
\hline
\end{tabular}

As shown above, 20,393 interactional metadiscourse items are totally employed in American corpus, whereas 3,743 markers appear in Chinese corpus. Due to the large difference in the total size of the two corpora, it is more reliable that this study counts these markers per 1,000 tokens. Even so, the incidence per 1,000 tokens of each type in American corpus is much larger than that in Chinese one. 
Table 2 further reveals that engagement markers and self-mentions are the most frequently employed both in American and Chinese corpus, whereas the type of attitude markers is the least frequently used in both corpora.

\subsection{The Significant Differences in Interactional Metadiscourse Markers}

The difference in frequency only cannot scientifically validates the distinctive features between the two corpora. In order to determine whether the difference in the use of these interactional metadiscourse is significant, Chi-square test is employed to further examine the statistical findings in Table 2. The testing results are shown in the Table 3.

Table 3. Chi-square test for the difference in interactional metadiscourse items

\begin{tabular}{|c|c|c|c|c|c|}
\hline \multirow{2}{*}{$\begin{array}{l}\text { Interactional metadiscourse } \\
\text { type }\end{array}$} & Frequency & Frequency & \multirow[b]{2}{*}{$\begin{array}{l}\text { Chi-square } \\
\text { value }\end{array}$} & \multirow[b]{2}{*}{ P-value } & \multirow{2}{*}{$\begin{array}{l}\text { Significant } \\
\text { difference }\end{array}$} \\
\hline & $\begin{array}{l}\text { in American } \\
\text { corpus }\end{array}$ & $\begin{array}{l}\text { in } \text { Chinese } \\
\text { corpus }\end{array}$ & & & \\
\hline attitude markers & 587 & 83 & 379.13 & 0.00 & yes \\
\hline boosters & 1055 & 175 & 629.59 & 0.00 & yes \\
\hline self-mentions & 7956 & 1475 & 4453.8 & 0.00 & yes \\
\hline engagement markers & 9216 & 1818 & 4960.2 & 0.00 & yes \\
\hline hedges & 1579 & 192 & 1079.7 & 0.00 & yes \\
\hline total & 145897 & 58041 & 37848 & 0.00 & yes \\
\hline
\end{tabular}

$\mathrm{P}$ value is set at 0.05 .

If the $\mathrm{p}$ value is tested to be smaller than 0.05 , it means the difference is significant. If the case is opposite, it claims that there is no significant difference. By Chi-square test, table 3 demonstrates that the use of interactional metadiscuorse has a significant difference in all five types of markers as $p$ value of each type is 0.00 that is much smaller than 0.05 . In order to further explain to what extent the difference exists in two corpora, the rhetorical functions of these markers are to be scrutinized as follows.

\subsection{The Employment of Interactional Metadiscourse and Realization of Rhetorical Functions}

Interactional metadiscourse plays a critical role in involving the reader for it helps the writer process and refine information out of concern for possible reactions to the propositions delivered (Hyland, 1998: 223). Interactional metadiscourse in this research is deployed to realize the rhetorical functions of echos and pathos, which address the purpose of persuasion of the letter to shareholders. This study finds out both American and Chinese Chairmen (CEOs or Presidents) employ five aspects of interactional metadiscourse in the letters. The letters of American companies are richer in the use of interactional metadiscourse and are therefore hypothesized to be more credibly and affectively appealing than these of Chinese companies.

\subsubsection{Integrating Self-mentions Markers to another Interactional Markers and Realization of Ethos}

Hyland (2005:78) argues that these interactional metadiscourse aspects of engagement markers, hedges, and boosters contribute most to the credibility appeals. Besides, self-mentions markers also do great contributions to build a positive personal and corporate image. Specifically, 7,656 self-mentions markers are extensively used in American letters compared to 1,475 in Chinese letters. Some self-mentions markers of $I$ and we appear in a much high frequency in both corpora. The Chi-square test only proves there is an obvious difference in frequency, but cannot explain how these differences exist. The following examination explores to what extent the distinctive features are different. 
Table 4. Collocation of $I$ and we in American and Chinese corpus

\begin{tabular}{|c|c|c|c|c|}
\hline \multicolumn{3}{|c|}{ American corpus } & \multicolumn{2}{|c|}{ Chinese corpus } \\
\hline $\begin{array}{l}\text { self-mentions } \\
\text { maker }\end{array}$ & $\begin{array}{l}\text { collocated } \\
\text { item }\end{array}$ & $\begin{array}{l}\text { the first word on the } \\
\text { right(frequency) }\end{array}$ & $\begin{array}{l}\text { collocated } \\
\text { item }\end{array}$ & $\begin{array}{l}\text { the first word on the } \\
\text { right(frequency) }\end{array}$ \\
\hline \multirow{3}{*}{ I } & boosters(32) & $\begin{array}{l}\text { believe(26) } \\
\text { think(6) }\end{array}$ & boosters $(0)$ & \\
\hline & hedges(21) & would(16)should(5) & hedges(17) & would(17) \\
\hline & $\begin{array}{l}\text { engagement } \\
\text { markers(12) }\end{array}$ & do not(7)should(5) & $\begin{array}{l}\text { engagement } \\
\text { markers }(0)\end{array}$ & \\
\hline \multirow{4}{*}{ we } & boosters(186) & $\begin{array}{l}\text { always(11)know(19)think(19) } \\
\text { must(40)believe(82) } \\
\text { established(5)never(10) }\end{array}$ & boosters(28) & $\begin{array}{l}\text { believe ( } 10) \\
\text { established(7)know } \\
\text { (6) realized(5) }\end{array}$ \\
\hline & hedges(69) & $\begin{array}{l}\text { would(41)might(9)may(9)could } \\
\text { (10) }\end{array}$ & hedges(10) & would(10) \\
\hline & $\begin{array}{l}\text { engagement } \\
\text { markers(114) }\end{array}$ & $\begin{array}{l}\text { do not (14) look (16) } \\
\text { see (26) need (44) find (5) add (9) }\end{array}$ & $\begin{array}{l}\text { engagement } \\
\text { markers(5) }\end{array}$ & $\operatorname{see}(5)$ \\
\hline & $\begin{array}{l}\text { attitude } \\
\text { markers(33) }\end{array}$ & expected(33) & $\begin{array}{l}\text { attitude } \\
\text { markers ( } 0 \text { ) }\end{array}$ & \\
\hline
\end{tabular}

The letter to shareholders aims to accentuate not only the positive corporate image, but personal authority, decisiveness, or conviction. The perceived integrity and authority of the writer, (herein Chairman, CEO or President) is particularly important in the letters (Jacobson, 1988, p. 52) where honesty (Cato, 1994, p. 29) and candour (Poe, 1994) are regarded as crucial elements of effective communication. The data shows that self-mentions markers, for example $I$ or we are used by Chairman (CEO or President) to present a competent, trustworthy, authoritative and honest persona (Hyland, 2005). Hyland (2005) mentions that the rhetorical use of metdadiscourse in the construction of CEO's ethos is double-edged, which means self-mentions markers collaborate not only with boosters but hedges. Boosters allow the writer to present a credible image of authority, decisiveness, and conviction, whereas hedges demonstrate personal honesty and integrity through willingness to address hard realities, albeit behind a shield of mitigation. By taking two highly used self-mentions markers of $I$ and we as typical examples, this study applies the function of pattern in WordSmith and reveals the two pronouns' collocation patterns, which helps observe the first word on the right to them. The results of the collocation and frequency in these words are shown in Table 4.

The above table depicts that self- mentions of $I$ directly links boosters, hedges and engagement markers and the item of we even collaborates with attitude markers besides three types of markers in American corpus. By contrast, It is interesting that in Chinese corpus there are only three words of would, am, and will directly appear on the right of $I$. The word of $I$ doesn't diversely link with another interactional metadiscourse markers except for hedges. As for the item of we, it seems that Chinese companies prefer to connect it with boosters, hedges and engagement markers, for the collocations with the attitude markers items are not found in Chinese data.

Hyland (2005) argues that self-mentions with epistemic verbs of judgment for instance believe and think underlie an overt acceptance of personal responsibility, and an explicit attempt to build a personal ethos of competence and authority. The two epistemic verbs belong to boosters. Therefore, there is no doubt that the combination between the first person pronouns of $I$ and we and boosters items as a strategy clearly promotes the determined, confident and positive image at the helm of the company. These findings strongly support that American companies are more flexible in diversely integrating interactional metadiscourse into establishing ethos.

1) Our target again will be a Clayton Home porch, located precisely 35 feet from the throwing line. When I was a teenager -in my one brief flirtation with honest labor -1 tossed about 500,000 papers. So I think I'm pretty good. Challenge me! Humiliate me! Knock me down a peg!

Berkshire Hathaway in 2014

2) In fact, when Mr. Market gets very moody and depressed, we think it might be a good time to buy back stock. 
J.P. Morgan Chase \& Co. in 2014

3) We never take for granted the trust our customers have placed in us, and we understand the important role we play in helping grow the U.S. economy. If we serve our customers well and manage our business effectively and efficiently, we also will grow and succeed as a company. As we like to say, we never put the stagecoach ahead of the horses!

\section{Wells Fargo in 2015}

As in above examples, self-mentions markers are combined with boosters, for example, I think, we think, and we never etc. are used to provide expressions of personal belief or judgment. It seemingly mitigates the tone, but actually strengthens the writer's presence in the letter. In doing so, the letter directly aligns the writer with the views expressed and in fact highlights the personal authority and integrity, thereby establishing credibility and gaining trust.

It is suggested that the counterparts in Chinese companies should flexibly employ interactional metadisourse, as it has been justified that interactional metadiscourse is an effective means of building a positive and credible image (Hyland 1998), which facilitates trust gained from the reader. In addition, Chinese companies can learn to fully use the integration of interactional metadiscourse. For instance self-mentions can be used with boosters, hedges, engagement markers, or even attitude markers to present the integrity, responsibility, or fairness image to their readers.

\subsubsection{Engagement Markers and Realization of Pathos}

Pathos in other words means to make affective appeals. In particular, the letter to shareholders essentially aims to get involved with the reader as closely as possible and plays a function of persuasion. Interactional metadiscourse helps accomplish the affective appeal by proposing agreement on the claims discussed by projecting oneself as a person with similar ideas, interests and objectives as the reader, demonstrating common ground with the reader, addressing the reader directly and making the reader inclusive.

Table 5. The frequency of model verbs between American and Chinese corpus

\begin{tabular}{lll}
\hline $\begin{array}{l}\text { Engagement } \\
\text { markers(model verbs) }\end{array}$ & Frequency in American corpus & Frequency in Chinese corpus \\
\hline have to & 34 & 1 \\
must & 65 & 7 \\
need to & 82 & 4 \\
should & 122 & 7 \\
total & 303 & 19 \\
\hline
\end{tabular}

Table 2 above presents that engagement markers are more extensively used in the letters in American corpus than in Chinese corpus. To be specific, one of widely used items in engagement markers is found to be model verbs such as have to, must, need to, and should. These words convey the message that something should be done and simultaneously align the goals and desires of the writer with those of the reader. It is clear that these model verbs rhetorically imply that the reader are suggested to concur.

4) In 2015, data security supplanted branch location as the top reason a consumer chooses one bank over another, and we have to continue to be very good in this space to maintain the trust of the people and organizations we serve.

PNC Financial Service in 2015

5) While we must consistently try to "see around corners" to anticipate problems, we also see plenty of reasons for optimism.

Goldman Sachs Group in 2015

6) Our goal is simple: We do not need to be the largest in the business, but we want to be the best for the clients we serve.

Bank of American Corp. in 2014 
7) Everyone should look to simplify and seek out best practices, including asking our regulators for guidance.

J.P. Morgan Chase \&Co. in 2015

These sentences in these examples show the writers state their subjective ideas or suggestions overtly and impart a force indirectly by these model verbs, which arouses the empathy and gains agreement from the reader. Although these model verbs have an implicitly powerfully persuasive force to make the reader convinced, they are hardly found in the Chinese corpus (Table 5). In terms of the frequency of all the four model verbs, they are totally counted to be 19 times in Chinese corpus, while 303 times in American corpus.

Another engagement markers of you and your are observed to be highly active in American corpus, too. They are used to directly address the reader. There is no doubt that it is easier to call the reader's attention and make him (her) feel more involved. Furthermore, the inclusive pronouns of our (inclusive), us (inclusive), we (inclusive) are more closely involved with the reader directly. They explicitly seek to establish the common ground and draw the reader into the discourse as a participant. These items help shorten the distance between the writer and reader, which obviously appeal to the reader. The table below shows the incidence in these personal pronouns in the two corpora.

Table 6. The frequency of personal pronouns in American and Chinese corpus

\begin{tabular}{lll}
\hline Engagement markers(s) & Frequency in American corpus & Frequency in Chinese corpus \\
\hline you & 376 & 33 \\
your & 139 & 3 \\
our & 3540 & 647 \\
us & 379 & 82 \\
we & 3354 & 650 \\
total & 7788 & 1415 \\
\hline
\end{tabular}

The sharp difference in use frequency discloses that Chinese companies do not adequately employ these pathos functional engagement markers to affectively appeal to the reader. As the promotional genre, Chinese Chairmen (CEOs or Presidents) are suggested to fully use these markers to effectively build close writer-reader relationship.

\section{Conclusion}

In sum, this study collects the letters to shareholder written in English in 2014 and 2015 of American and Chinese financial companies and builds two small corpora. By WordSmith, we identify the difference in frequency of interactional metadiscourse markers and their collocations. And then Chi-square test further proves that the difference is significant. In order to find to what extent the use is different, the rhetorical functions of ethos and pathos are taken into consideration, which properly addresses the promotional and persuasive purposes in the letters.

We firstly find out that five types of interactional metadiscourse of attitude markers, boosters, self-mentions, engagement markers and hedges are all used by both American and Chinese companies to achieve their communicative purposes. Despite this, there is a large difference in incidence of these markers. Each type of markers in American corpus is much more frequently used than that in Chinese corpus. The study then takes self-mentions and engagement markers as specific examples to demonstrate how differently these markers are used between American and Chinese corpus. It is found that the self-mentions marker of $I$ in American corpus not only collaborates with boosters, which builds up the authority, decisiveness or conviction, but with hedges aiming to achieve an honesty or integrity impression on the reader. By contrast, it is identified to use with hedges only in Chinese corpus. Furthermore the self-mentions marker of we is more tactically integrated to the other four interactional metadiscourse in American corpus than that in Chinese. Finally, observing the difference in engagement markers reveals that the model verbs and the personal pronouns are more widely used to get involved with the reader in American corpus than these in Chinese corpus.

This study further confirms that interactional metadiscourse items can be employed to realize distinctive rhetorical functions. Moreover, American corpus shows that the extensive use of all types of interactional metadiscourse plays an effective role in achieving the communicative purposes of the letter as a promotional 
genre. These findings firstly suggest that Chinese Chairmen (CEOs or Presidents) should fully employ each type of interactional metadiscourse markers to help align the writer and reader as American counterparts do. Secondly, they are suggested to deploy the integration of interactional metadiscourse markers more frequently and flexibly in order to build up a positive personal or corporate image and then persuade the reader more effectively. The study also gives an insight to the pedagogical practitioners who are teaching business writing and reading.

\section{References}

Ädel, A. (2006). Metadiscourse in L1 and L2 English. Amsterdam: John Benjamins. https://doi.org/10.1075/scl.24

Aerts, W. \& Yan, B.B. (2017). Rhetorical impression management in the letter to shareholders and institutional setting: A metadiscourse perspective. Accounting, Auditing \& Accountability Journal, 30(2), 404-432. https://doi.org/10.1108/AAAJ-01-2015-1916

Amernic, J., Craig, R., \& Tourish, D. (2010). Measuring and assessing tone at the top using annual report CEO letters, Institute of Chartered Accountants of Scotland.

Anderson, C., \& Imperia, G. (1992). The corporate annual report: a photo analysis of male and female portrayals. Journal of Business Communication, 29, 113-28. https://doi.org/10.1177/002194369202900201

Bunton, D. (1999). The use of higher level metatext in PhD theses. English for Specific Purposes, 18, 41-56. https://doi.org/10.1016/S0889-4906(98)00022-2

Carrio-Pastor, M. L., \& Calderon, R. M. (2015). A contrastive analysis of metadisourse features in business e-mails written by non-native speakers of English. Procedia-Social and Behavioral Sciences, 173, 214-221. https://doi.org/10.1016/j.sbspro.2015.02.055

Cato, S. (1994). The ten best and ten worst annual reports. Chief Executive, 98, 26-33.

Conaway, R. N., \& Wardrope, W. J. (2010). Do their words really matter? Thematic analyses of US and Latin CEO Letters. Journal of Business Communication, 47(2), 141-168. https://doi.org/10.1177/0021943610364523

Crawford Camiciottoli, B. (2010). Discourse connectives in genres of financial disclosure: earnings presentations vs earnings releases. Journal of Pragmatics, 42, 650-663. https://doi.org/10.1016/j.pragma.2009.07.007

Crismore, A. (1989). Talking with Readers: Metadiscourse as Rhetorical Act. New York, NY: Peter Lang Publishers.

Crismore, A., \& Farnsworth, R. (1990). Metadiscourse in popular and professional science discourse. In W. Nash (Ed.), The Writing Scholar: Studies in Academic Discourse. Newbury Park, CA: Sage.

Dahl, T. (2004). Textual metadiscourse in research articles: a marker of national culture or of academic discipline? Journal of Pragmatics, 36, 1807-1825. https://doi.org/10.1016/j.pragma.2004.05.004

Dragsted, B. (2014). A case study of letters to shareholders in annual reports before, during and after the financial crisis. LSP Journal, 5(2), 84-104.

Fuertes-Olivera, P., Velasco-Sacristan, M., Arribas-Bano, A., \& Samaniego Fernandez, E. (2001). Persuasion and advertising English: metadiscourse in slogans and headlines. Journal of Pragmatics, 33, 1291-1307. https://doi.org/10.1016/S0378-2166(01)80026-6

Harris, Z. (1959). Linguistics transformations for information retrieval. In Papers in Structural and Transformational Linguistics. Dordrecht: D. Reidel.

Hyland, K. (1998). Exploring corporate rhetoric: Metadiscourse in the CEO's letter. Journal of Business communication, 35(2), 224-45. https://doi.org/10.1177/002194369803500203

Hyland, K. (2000). Disciplinary Discourses: Social Interactions in Academic Writing. London: Longman.

Hyland, K. (2002a). Authority and indivisibility: authorial identity in academic writing. Journal of Pragmatics, 34(8), 1091-1112. https://doi.org/10.1016/S0378-2166(02)00035-8

Hyland, K. (2002b). Academic argument: induction or interaction? Resvist canaria De Estudios Ingeleses, 44, 29-45.

Hyland, K. (2004). Disciplinary interactions: metadiscourse in L2 postgraduate writing. Journal of Second Language Writing, 13, 133-151. https://doi.org/10.1016/j.jslw.2004.02.001

Hyland, K. (2005). Metadiscourse: Exploring Interaction in Writing. London/New York: Continuum 
Hyland, K., \& Jiang, F. (2016). Metadiscursive nouns: Interaction and cohesion in abstract moves. English for Specific Purposes, 46, 1-14. https://doi.org/10.1016/j.jeap.2016.01.005

Hyland, K., \& Tse, P. (2004). Metadiscourse in academic writing: A reappraisal. Applied Linguistics, 25(2), 156-77. https://doi.org/10.1093/applin/25.2.156

Jacobson, G. (1988). How valuable is the annual report? Management Review, 51(3).

Kan, M. O. (2016). The use of Interactional Metadiscourse:A Comparison of Articles on Turkish Education and Literature. Educational Sciences: Theory \& Practice, 16(5), 1639-1648. https://doi.org/10.12738/estp.2016.5.0196

Mirshamsi, A., \& Allami, H. (2013). Metadiscourse markers in the discussion/conclusion section of Persian and English master's theses. The Journal of Teaching Language Skills (JTLS), 32(3), 23-40.

Mu, C.J., Zhang, L. J., Ehrich, J., \& Hong, H. Q. (2015). The use of metadiscourse for knowledge construction in Chinese and English research articles. Journal of English for Academic Papers, 20, 135-148. https://doi.org/10.1016/j.jeap.2015.09.003

Ozdemir, N. O., \& Longo, B. (2014). Metadiscourse Use in Thesis Abstracts: A Cross-cultural Study, ProcediaSocial and Behavioral Sciences, 141, 59-63.

Poe, R. (1994). Can we talk? Across the Board, 31(5), 17-23.

Schiffrin, D. (1980). Metatalk: organisational and evaluative brackets in discourse. Sociological Inquiry, 50(3-4), 199-236. https://doi.org/10.1111/j.1475-682X.1980.tb00021.x

Thompson, G. (2001). Interaction in academic writing: learning to argue with the reader. Applied Linguistics, 22(1), 58-78. https://doi.org/10.1093/applin/22.1.58

Thompson, G., \& Thetela, P. (1995). The sound of one hand clapping: the management of interaction in writtten discourse. TEXT, 15(1), 103-27. https://doi.org/10.1515/text.1.1995.15.1.103

Vande Kopple, W. J. (1985). Some exploratory discourse on metadiscourse. College Composition and Communication, 36, 82-93. https://doi.org/10.2307/357609

Vande Kopple, W. J. (2002). Metadiscourse, discourse, and issues in composition and rhetoric. In E. Barton, \& G Stygall (Eds.), Discourse Studies in Composition (pp. 91-113). Gresskill, NJ:Hampton Press.

Williams, J. M. (1981). Style: Toward Clarity and Grace. Chicago: The University of Chicago Press.

Yuthas, K., Rogers, R., \& Dillard, J. F. (2002). Communicative action and corporate annual reports. Journal of Business Ethics, 41(1), 141-157. https://doi.org/10.1023/A:1021314626311

\section{Copyrights}

Copyright for this article is retained by the author(s), with first publication rights granted to the journal.

This is an open-access article distributed under the terms and conditions of the Creative Commons Attribution license (http://creativecommons.org/licenses/by/4.0/). 